\title{
Prominent Schwannian Stroma Present
}

National Cancer Institute

\section{Source}

National Cancer Institute. Prominent Schwannian Stroma Present. NCI Thesaurus. Code C42049.

A finding indicating the presence of a Schwann cell-rich stromal component in a neoplastic tissue specimen. 